\title{
HUBUNGAN PENGETAHUAN IBU DAN POLA PEMBERIAN MAKANAN TERHADAP STATUS GIZI ANAK USIA TODDLER
}

\author{
Fitriana Noor Khayati*, Ririn Munawaroh \\ Program Studi Ilmu Keperawatan \\ STIKES Muhammadiyah Klaten, Klaten, 57419, Jawa Tengah, Indonesia \\ *) E-mail : fnoorkhayatī@gmail.com
}

Dikirim: Maret 2017, diterbitkan: April 2017

\begin{abstract}
ABSTRAK
Tujuan penelitian: untuk menganalisis hubungan pengetahuan ibu tentang gizi balita dan pola pemberian makanan terhadap status gizi anak usia toddler. Metode: Penelitian ini bersifat deskriptif analitik dengan pendekatan cross sectional. Populasi dalam penelitian ini yaitu ibu yang memiliki anak usia 1-3 tahun di Desa Kunden, Karanganom, Klaten. Sampel berjumlah 56 orang yang diambil dengan teknik concecutive sampling. Penelitian dilaksanakan pada bulan Juni-Juli 2016. Instrumen yang digunakan ialah kuesioner pengetahuan ibu tentang status gizi, kuesioner pola pemberian makanan, timbangan berat badan, serta stature meter. Pengukuran status gizi menggunakan indeks BB/TB. Analisis data menggunakan uji koefisien kontingensi untuk mengetahui korelasi. Hasil: Ibu yang memiliki pengetahuan tentang gizi balita cukup baik sejumlah $41,1 \%$ dan ibu yang memiliki pengetahuan tentang pola pemberian makanan baik sejumlah 78,6\%. Balita di Desa Kunden sebagian besar memiliki status gizi normal, yaitu sejumlah 62,5\%. Hasil uji statistik menunjukkan tidak ada hubungan pengetahuan ibu $(\mathrm{p}=0,166)$ dan pola pemberian makanan $(\mathrm{p}=0,313)$ terhadap status gizi balita $(\alpha=0,05)$. Kesimpulan: Tidak ada hubungan antara pengetahuan ibu tentang gizi anak usia toddler dan pola pemberian makanan terhadap status gizi anak usia toddler.
\end{abstract}

Kata Kunci: pengetahuan ibu, pola pemberian makanan, status gizi, toddler

\section{CORRELATION OF MOTHER'S KNOWLEDGE AND FEEDING PATTERN WITH NUTRITIONAL STATUS IN TODDLERS}

\section{ABSTRACT}

Objective: to analyze the correlation of mother's knowledge about toddler's nutrition and feeding pattern with nutritional status of toddlers. Methods: This research was analytical descriptive with cross sectional approach. The population was mothers who had children aged 1-3 years in Kunden, Karanganom Village, Klaten. Samples consisted of 56 people taken using consecutive sampling technique. The research was conducted in June-July 2016. The instruments used were a questionnaire of mother's knowledge about nutritional status, feeding pattern questionnaire, body weight scales, and stature meter. The nutritional status was measured using Weight/Height index. Data were analyzed using contingency coefficient test to figure out the correlation. Results: $41.1 \%$ of mothers had relatively good knowledge about nutrition of toddler and $78.6 \%$ mothers had good knowledge about feeding pattern. $62.5 \%$ of toddlers in Kunden Village mostly had normal nutritional status. The results of statistical test showed that there was no correlation of mother's knowledge $(p=0.166)$ and feeding pattern ( $p=0.313)$ with nutritional status of toddles $(\alpha=0.05)$. Conclusion: There is no correlation of mother's knowledge about toddlers'nutrition and feeding pattern with nutritional status of toddlers.

Keywords: mother's knowledge, feeding pattern, nutritional status, toddlers

\section{LATAR BELAKANG}

Masa balita merupakan periode yang sangat penting dalam proses tumbuh kembang manusia. Masa tumbuh kembang di usia ini merupakan masa yang berlangsung cepat dan tidak akan pernah terulang. Karena itu, masa balita sering disebut golden age atau masa keemasan. Proses pertumbuhan 
dan perkembangan pada balita dipengaruhi oleh beberapa faktor, salah satunya gizi atau nutrisi (Depkes, 2009). Nutrisi yang tidak terpenuhi dengan baik akan menghambat pertumbuhan dan perkembangan anak serta menyebabkan berbagai masalah kesehatan terkait gizi (Hidayat, 2009).

United Nation of Childrens Fund (UNICEF) pada tahun 2012 menyebutkan bahwa sebanyak 152.000 balita di Indonesia meninggal setiap tahunnya. UNICEF (2012) menjelaskan bahwa 32\% penyebab kematian bayi dan balita ialah penyakit infeksi, seperti pneumonia dan diare, sedangkan World Health Organisation (2016) menjelaskan bahwa kondisi kekurangan nutrisi berhubungan dengan $45 \%$ kematian anak. Indonesia tercatat sebagai negara yang memiliki masalah kekurangan gizi nomor 5 di dunia pada tahun 2012. Data Riset Kesehatan Dasar (Riskesdas) tahun 2013 menyebutkan bahwa jumlah balita gizi buruk dan kurang di Indonesia mengalami peningkatan menjadi $19,6 \%$ atau sekitar 4,5 juta dibanding tahun 2010. Riskesdas 2013 menunjukkan Provinsi Jawa Tengah termasuk dalam salah satu provinsi yang mengalami peningkatan prevalensi balita gizi kurang dan balita pendek menjadi $17,6 \%$ dan 37\% (Badan Penelitian dan Pengembangan Kesehatan Kementerian Kesehatan RI, 2013).

Data Dinas Kesehatan Kabupaten Klaten (2015) menunjukkan prevalensi balita yang mengalami gizi kurang meningkat dari 3,65\% atau 2.496 balita pada tahun 2012 menjadi $4,81 \%$ atau 3.306 balita, sedangkan balita yang mengalami gizi lebih meningkat dari 0,99\% pada tahun 2012 menjadi 1,69\%. Data Dinas Kesehatan Kabupaten Klaten (2015) menyebutkan daerah yang paling banyak memiliki balita dengan masalah gizi kurang di Kabupaten Klaten ialah Kecamatan Karanganom. Prevalensi balita dengan gizi kurang di Kecamatan Karanganom menunjukkan peningkatan dari 87 balita atau 3,96\% pada tahun 2012 menjadi 283 balita atau $12,62 \%$.

Status gizi seseorang dipengaruhi oleh beberapa faktor, baik secara langsung maupun tidak langsung. Ketidaksesuaian antara jumlah gizi yang diperoleh dan kebutuhan gizi serta penyakit infeksi, seperti diare dapat memengaruhi status gizi secara langsung, tergantung pada besarnya dampak yang ditimbulkan. Faktor yang secara tidak langsung memengaruhi status gizi ialah pengetahuan, persepsi, kebiasaan makan, dan kondisi sosial ekonomi (Proverawati \& Kusumawati, 2011). Prevalensi balita dengan status gizi kurang yang cenderung meningkat apabila tidak diatasi akan menyebabkan masalah kesehatan yang lebih serius. Oleh sebab itu, perlu dilakukan upaya untuk menekan prevalensi balita dengan status gizi kurang.

Upaya yang dapat dilakukan untuk menekan kejadian balita dengan status gizi kurang ialah meningkatkan mutu gizi perorangan dan masyarakat dengan cara memperbaiki pola konsumsi makanan yang sesuai dengan gizi seimbang, memperbaiki perilaku sadar gizi, aktivitas fisik, meningkatkan akses dan mutu pelayanan gizi sesuai dengan kemajuan ilmu pengetahuan dan teknologi, serta meningkatkan sistem kewaspadaan pada pangan dan gizi (Kusharto \& Supariasa, 2014).

Peran masyarakat, terlebih keluarga yang memiliki anak balita sangat dibutuhkan dalam upaya menekan angka kejadian balita dengan status gizi kurang, mengingat anak balita masih banyak bergantung pada orangtua atau pengasuhnya dalam pemenuhan kebutuhan nutrisi. Anak usia balita belum dapat menyebutkan nama makanan yang diinginkan. Oleh sebab itu, orangtualah yang bertugas mengatur dan memilihkan makanan 
yang bergizi untuk anaknya (Rusilanti \& Yulianti, 2015). Pola pemberian makanan yang dilakukan orangtua sangat penting bagi status kesehatan gizi balita. Karena itu, dalam pemilihan, penyusunan, dan penyajian makanan yang adekuat diperlukan pengetahuan (Santoso, 2008).

Berdasarkan hasil wawancara dengan petugas kesehatan di Puskesmas Karanganom pada tanggal 4 Maret 2016, desa dengan masalah gizi paling banyak selama periode Agustus-Oktober 2015 ialah Desa Kunden. Sebanyak $12,33 \%$ atau 17 balita memiliki status gizi kurang, 0,75\% atau satu balita memiliki status gizi lebih, $0,75 \%$ atau satu balita memiliki status gizi buruk, dan sebanyak $86,46 \%$ atau 114 balita memiliki status gizi baik.

Hasil yang didapatkan dari wawancara dengan 10 ibu yang memiliki balita dengan status gizi bermasalah pada tanggal 19 Maret 2016 di Dukuh Sayuran, Desa Kunden terkait pengetahuan gizi ialah 6 dari $10 \mathrm{ibu}$ mengetahui zat gizi yang diperlukan oleh tubuh, makanan yang perlu diberikan sesuai usia anak, dan akibat yang ditimbulkan apabila kebutuhan gizi tidak tercukupi.

Hasil yang didapatkan dari wawancara terkait pola pemberian makanan ialah 4 dari 10 ibu memberikan makanan sesuai dengan kebutuhan anak, memberikan makanan dengan frekuensi sedikit tapi sering, juga memberikan makanan yang disukai anaknya, serta memberikan makanan yang beraneka ragam sehingga anak mau makan. Sementara itu, 6 ibu masih memaksa anak menghabiskan makanan dalam jumlah banyak, juga hanya membiarkan jika anak tidak mau makan.

Tujuan penelitian ini ialah untuk menganalisis hubungan pengetahuan ibu dan pola pemberian makan terhadap status gizi anak usia toddler.

\section{METODE}

Penelitian ini merupakan penelitian deskriptif analitik dengan menggunakan pendekatan cross sectional. Penelitian dilaksanakan pada bulan Juni-Juli 2016 di Desa Kunden, Kecamatan Karanganom, Kabupaten Klaten. Populasi dalam penelitian ini ialah ibu yang memiliki anak usia 1-3 tahun di Desa Kunden yang berjumlah 66 orang. Pengambilan sampel dalam penelitian ini menggunakan teknik consecutive sampling dan didapatkan besar sampel sebanyak 56 orang yang memenuhi kriteria inklusi dan eksklusi. Kriteria inklusi dalam penelitian ini ialah ibu yang memiliki anak usia 1-3 tahun, dapat berkomunikasi secara verbal, dan aktif mengikuti posyandu (selama 3 bulan berurutturut). Sementara itu, kriteria eksklusi dalam penelitian ini ialah ibu yang anaknya memiliki penyakit gizi seperti kekurangan energi, protein, yodium, dan vitamin $A$.

Instrumen yang digunakan dalam penelitian ini ialah kuesioner pengetahuan ibu tentang status gizi balita dan kuesioner pola pemberian makan, timbangan, dan stature meter. Kuesioner pengetahuan gizi ibu diambil dari penelitian Prasetya (2012). Kuesioner ini terdiri atas sepuluh pertanyaan dengan skala Guttman (benar atau salah) tentang status gizi, manfaat gizi, komponen zat gizi, dan pemberian makan. Ibu dinilai pengetahuannya kurang bila nilai $<60 \%$, cukup bila nilai $60-75 \%$ dan baik bila nilai $>75 \%$.

Kuesioner pola pemberian makanan balita diambil dari penelitian Lestari (2006). Kuesioner ini terdiri atas 15 pertanyaan dengan skala Likert (selalu, sering, kadang-kadang, dan tidak pernah) tentang penyusunan menu, pemilihan bahan makanan, pengolahan dan penyajian makanan, serta cara pemberian makanan pada anak. Pola pemberian makan dikategorikan baik bila nilai $>75 \%$, cukup bila nilai $60-75 \%$, dan kurang bila nilai $<60 \%$. 
Kedua kuesioner telah diuji validitas pada 20 ibu yang memiliki anak usia 1-3 tahun di Desa Brangkal dengan hasil nilai $r$ hitung kuesioner pengetahuan gizi ibu 0,461-0,737 sehingga $r$ hitung $>r$ tabel 0,444 dan hasil uji validitas kuesioner pola pemberian makan didapatkan $r$ hitung 0,491-0,751 ( $r$ hitung $>r$ tabel). Kuesioner pengetahuan gizi ibu telah diuji reliabilitas dengan uji Kuder Richardson 20 karena berbentuk skala Guttman dengan nilai $r=0,778$ (reliabel). Kuesioner pola pemberian makanan juga telah diuji reliabilitas dengan uji alfa Cronbach karena berbentuk skala Likert dengan hasil $r=0,901$ (reliabel). Status gizi diukur melalui antropometri dan menggunakan indeks BB/TB yang kemudian dihitung nilai Z-score.

Peneliti mencari daftar nama anak usia toddler di bidan desa untuk menyeleksi anak yang memiliki masalah kekurangan energi protein, yodium, dan vitamin A. Kemudian, peneliti melakukan penelitian secara door to door dan memberikan informed consent.
Peneliti membagikan kuesioner kepada ibu dan mengukur berat badan dan tinggi badan anak. Timbangan berat badan yang digunakan timbangan OneMed $\AA$ dengan nomor sertifikat ONE MED/BR 2016/ J1504249128. Status gizi diukur melalui pengukuran berat badan dan tinggi badan. Status gizi dikategorikan menjadi dua, yaitu tidak normal dan normal. Status gizi normal apabila nilai Z-score antara -2 SD sampai dengan 2 SD, sedangkan status gizi tidak normal apabila nilai Z-score $<-2$ SD atau $>2$ SD. Analisis univariat dalam penelitian ini menggunakan frekuensi dan persentase, sedangkan analisis bivariat menggunakan uji statistik koefisien kontingensi.

\section{HASIL}

Analisis univariat dalam penelitian ini dilakukan untuk menggambarkan distribusi frekuensi karakteristik responden dan variabel yang diteliti. 


\section{Karakteristik Responden}

Tabel 1. Karakteristik responden di Desa Kunden, Kecamatan Karanganom, Kabupaten Klaten tahun 2016

\begin{tabular}{|c|c|c|}
\hline Variabel & $\begin{array}{c}\text { Frekuensi } \\
\text { (f) }\end{array}$ & $\begin{array}{c}\text { Persentase } \\
(\%)\end{array}$ \\
\hline \multicolumn{3}{|l|}{ Usia Anak } \\
\hline $12-24$ bulan & 34 & 60,7 \\
\hline 25-36 bulan & 22 & 39,3 \\
\hline \multicolumn{3}{|l|}{ Jenis Kelamin } \\
\hline Laki-laki & 26 & 46,4 \\
\hline Perempuan & 30 & 53,6 \\
\hline \multicolumn{3}{|l|}{ Usia Ibu } \\
\hline $20-35$ tahun & 44 & 78,6 \\
\hline$>35$ tahun & 12 & 21,4 \\
\hline \multicolumn{3}{|l|}{ Pendidikan Ibu } \\
\hline SD & 5 & 8,9 \\
\hline SMP & 12 & 21,4 \\
\hline SMA & 32 & 57,2 \\
\hline Perguruan tinggi & 7 & 12,5 \\
\hline \multicolumn{3}{|l|}{ Status Bekerja lbu } \\
\hline Tidak bekerja & 26 & 46,4 \\
\hline Buruh pabrik & 18 & 32,1 \\
\hline Wiraswasta & 8 & 14,3 \\
\hline PNS & 4 & 7,2 \\
\hline \multicolumn{3}{|l|}{ Pendapatan Keluarga } \\
\hline$<\operatorname{Rp} 500.000,00$ & 13 & 23,2 \\
\hline Rp $500.000,00-$ & & \\
\hline Rp1.000.000,00 & 17 & 19, \\
\hline$>\mathrm{Rp} 1.000 .000,00$ & 32 & 57,1 \\
\hline \multicolumn{3}{|l|}{ Pengetahuan Ibu } \\
\hline Baik & 19 & 33,9 \\
\hline Cukup & 23 & 41,1 \\
\hline Kurang & 14 & 25,0 \\
\hline \multicolumn{3}{|l|}{ Pola Pemberian Makanan } \\
\hline Baik & 44 & 78,6 \\
\hline Cukup & 12 & 21,4 \\
\hline Kurang & 0 & 0 \\
\hline \multicolumn{3}{|l|}{ Status Gizi } \\
\hline Tidak normal & 21 & 37,5 \\
\hline Normal & 35 & 62,5 \\
\hline Total & 56 & 100,0 \\
\hline
\end{tabular}

Sebagian besar anak yang menjadi responden dalam penelitian ini ialah anak berusia 12-24 bulan dengan persentase sebesar $60,7 \%$. Sebagian besar anak yang menjadi responden dalam penelitian ini berjenis kelamin perempuan, yaitu sejumlah $53,6 \%$.

Sebagian besar ibu yang menjadi responden penelitian berusia 20-35 tahun dengan persentase sebanyak $78,6 \%$. Sebagian besar tingkat pendidikan ibu sudah cukup tinggi, yaitu sebesar $57,1 \%$ ibu merupakan lulusan SMA. Ibu-ibu di Desa Kunden sebagian besar merupakan ibu rumah tangga (tidak bekerja) dengan persentase sebesar $46,4 \%$. Pendapatan rata-rata keluarga per bulan berdasarkan jumlah anggota keluarga sebagian besar Rp. 500.000-Rp1.000.000,00 dengan persentase sebesar $57,1 \%$.

Sebagian besar ibu-ibu di Desa Kunden memiliki pengetahuan tentang gizi anak yang cukup baik dengan persentase sebesar $41,1 \%$. Sebesar $78,6 \%$ ibu di Desa Kunden telah melakukan pola pemberian makanan yang baik. Sebagian besar anak di Desa Kunden memiliki status gizi normal, yaitu sebesar $62,5 \%$. 


\section{Hubungan Pengetahuan Ibu tentang Gizi Anak Usia Toddler terhadap Status Gizi Anak Usia Toddler}

Tabel 2. Hubungan pengetahuan ibu tentang gizi anak usia toddler terhadap status gizi anak usia toddler $(n=56)$

\begin{tabular}{|c|c|c|c|c|c|c|c|c|c|}
\hline \multirow{4}{*}{ Variabel } & & \multirow{2}{*}{\multicolumn{6}{|c|}{$\begin{array}{c}\text { Status Gizi Anak Usia Toddler } \\
\text { Berdasarkan Indeks BB/TB }\end{array}$}} & \multirow{4}{*}{$p$ value } & \multirow{4}{*}{$r$} \\
\hline & & & & & & & & & \\
\hline & & \multicolumn{2}{|c|}{ Tidak Normal } & \multicolumn{2}{|c|}{ Normal } & \multicolumn{2}{|c|}{ Total } & & \\
\hline & & $\mathbf{F}$ & $\%$ & $F$ & $\%$ & $f$ & $\%$ & & \\
\hline Pengetahuan & Kurang & 8 & 38,1 & 6 & 17,1 & 14 & 25,0 & & \\
\hline Ibu tentang Gizi & Cukup & 6 & 28,6 & 17 & 48,6 & 23 & 41,1 & 0,166 & 0,245 \\
\hline \multirow{2}{*}{ Balita } & Baik & 7 & 33,3 & 12 & 34,3 & 19 & 33,9 & & \\
\hline & Total & 21 & 100,0 & 35 & 100,0 & 56 & 100,0 & & \\
\hline
\end{tabular}

Hasil uji koefisen kontingensi pada Tabel 2 menunjukkan bahwa tidak ada hubungan antara pengetahuan ibu tentang gizi anak usia toddler terhadap status gizi anak yang

didukung dengan nilai $p$ value yang lebih besar dari nilai $\alpha=0,05$, yaitu 0,166 sehingga menerima hipotesis nol $(\mathrm{Ho})$.

\section{Hubungan Pola Pemberian Makanan terhadap Status Gizi Anak Usia Toddler}

Tabel 3. Hubungan pola pemberian makanan terhadap status gizi anak usia toddler $(n=56)$ Status Gizi Balita Berdasarkan Indeks BB/

\begin{tabular}{|c|c|c|c|c|c|c|c|c|c|}
\hline \multirow{3}{*}{\multicolumn{2}{|c|}{ Variabel }} & \multicolumn{4}{|c|}{ TB } & \multirow{2}{*}{\multicolumn{2}{|c|}{ Total }} & \multirow{3}{*}{$p$ value } & \multirow{3}{*}{$r$} \\
\hline & & \multicolumn{2}{|c|}{ Tidak Normal } & \multicolumn{2}{|c|}{ Normal } & & & & \\
\hline & & $f$ & $\%$ & $F$ & $\%$ & f & $\%$ & & \\
\hline Pola Pem & nCukup & 3 & 14,3 & 9 & 25,7 & 12 & 21,4 & 0,313 & 0,134 \\
\hline Makanan & $\begin{array}{l}\text { Baik } \\
\text { Total }\end{array}$ & $\begin{array}{l}18 \\
21\end{array}$ & $\begin{array}{l}85,7 \\
100,0\end{array}$ & $\begin{array}{l}26 \\
35\end{array}$ & $\begin{array}{l}74,3 \\
100,0\end{array}$ & $\begin{array}{l}44 \\
\mathbf{5 6}\end{array}$ & $\begin{array}{l}78,6 \\
100,0\end{array}$ & 0,310 & 0,134 \\
\hline
\end{tabular}

Berdasarkan Tabel 3, hasil uji koefisien kontingensi menunjukkan bahwa tidak ada hubungan antara pola pemberian makanan terhadap status gizi anak usia toddler yang didukung dan nilai $p$ value yang lebih besar dari nilai $\alpha=0,05$ yaitu 0,313 sehingga menerima Ho.

\section{DISKUSI}

1. Pengetahuan Ibu tentang Gizi Anak Usia Toddler dan Pola Pemberian Makanan terhadap Status Gizi Anak Usia Toddler

Hasil penelitian di Desa Kunden menunjukkan sebagian besar anak usia toddler yang menjadi responden dalam penelitian ini ialah balita berusia 12-24 bulan dengan persentase sebesar $60,7 \%$. Usia batita merupakan usia ketika anak berperan sebagai konsumen pasif dan kelompok umur yang rawan gizi karena pada masa itu anak mudah sakit dan mengalami kurang gizi (Kusharto \& Supariasa, 2014). Anak balita merupakan kelompok usia yang menunjukkan pertumbuhan badan yang pesat sehingga anak memerlukan zat gizi yang tinggi setiap kilogram berat badannya. Rusilanti \& Yulianti (2015) menyebutkan bahwa semakin bertambah usia anak, keterampilan motorik anak akan semakin meningkat sehingga makanan yang disajikan harus bervariasi. Asupan makanan yang tidak terpenuhi dengan baik akan menyebabkan anak mengalami masalah gizi. Anak yang 
kurang gizi dapat dilihat dari berat dan tinggi badan yang kurang dari normal. Anak yang tinggi badannya tidak bertambah atau kurang dari normal menandakan kurang gizinya telah berlangsung lama (Maryunani, 2010).

Hasil penelitian di Desa Kunden menunjukkan sebagian besar anak usia toddler yang menjadi responden dalam penelitian ini adalah balita berjenis kelamin perempuan dengan persentase sebesar $53,6 \%$. Bardosono (2009) menjelaskan bahwa dari aspek kelompok dalam penduduk, perempuan dan anak-anak perempuan merupakan kelompok yang berisiko terkena kurang gizi karena masyarakat tertentu secara kultural lebih mementingkan alokasi makanan untuk laki-laki dewasa dan anak laki-laki. Ayu (2008) juga menjelaskan anak bahwa perempuan usia balita memiliki nafsu makan yang kurang sehingga memengaruhi pola konsumsi dan tingkat konsumsi yang bisa berakibat pada status gizi balita.

Hasil penelitian di Desa Kunden menunjukkan ibu yang paling banyak menjadi responden dalam penelitian ini adalah ibuibu yang termasuk dalam masa reproduksi sehat, yaitu ibu berusia 20-35 tahun dengan persentase sebesar $78,6 \%$. Usia merupakan salah satu faktor yang dapat memengaruhi kemampuan seseorang. Notoatmodjo (2010) menjelaskan bahwa umur, pendidikan dan pekerjaan merupakan faktor yang mempengaruhi pengetahuan seseorang.

Mubarak (2011) menyebutkan bahwa semakin dewasa usia seseorang, tingkat kemampuan dan kematangan dalam berpikir dan menerima informasi akan lebih baik daripada seseorang yang berusia lebih muda. Santrock (1999/2002) menyebutkan bahwa usia 20-35 tahun merupakan usia dewasa awal. Dewasa awal memiliki beberapa tugas perkembangan, di antaranya merawat dan mengasuh anak. Seorang ibu yang berada di usia dewasa awal memiliki tugas perkembangan yang perlu dilakukan agar dapat bertanggung jawab dalam kehidupan berkeluarga (Morks, Knoers, \& Haditono, 2001).

Hasil penelitian di Desa Kunden ialah sebagian besar ibu memiliki tingkat pendidikan yang tinggi dengan persentase sebesar $69,6 \%$. Pendidikan merupakan kebutuhan dasar manusia yang sangat diperlukan untuk mengembangkan diri. Tingkat pendidikan ibu sangat memengaruhi cara ibu memahami masalah gizi dan kesehatan balita. Notoatmodjo (2007) menjelaskan bahwa salah satu faktor yang berhubungan dengan status gizi balita ialah tingkat pendidikan ibu. Miller \& Rodgers (2009) menyebutkan bahwa ibu dengan tingkat pendidikan yang tinggi akan lebih mudah memahami dan menerima informasi, termasuk informasi tentang gizi dan kesehatan sehingga dapat meningkatkan pengetahuan gizi dan kesehatan yang selanjutnya akan menimbulkan sifat positif di bidang kesehatan.

Hasil penelitian di Desa Kunden menunjukkan bahwa sebagian besar ibu yang menjadi responden dalam penelitian ini adalah ibu-ibu pekerja dengan persentase sebesar 53,6\%. Usia balita adalah usia ketika anak belum dapat menyebutkan nama makanan yang diinginkan. Oleh sebab itu, orangtua bertugas mengatur dan memilihkan makanan yang bergizi untuk anaknya.

Ibu yang tidak bekerja dalam keluarga dapat memengaruhi asupan gizi balita karena ibu yang lebih banyak meluangkan waktunya di rumah dapat memberikan pengasuhan yang maksimal kepada anaknya (Agustina, 2015). Seorang ibu yang bekerja di luar rumah mempunyai risiko tidak dapat langsung menyiapkan dan memberi makanan untuk keluarga dan anak-anaknya karena waktunya tersita oleh pekerjaan. Seorang ibu yang bekerja di luar rumah hendaknya dapat membagi waktu dengan baik antara 
pekerjaan dan tugas penyelenggaraan makanan keluarga (Miller \& Rodgers, 2009).

Hasil penelitian ini menunjukkan bahwa sebagian besar keluarga di Desa Kunden memiliki pendapatan yang tinggi, yaitu sebesar $57,1 \%$. Kebutuhan gizi sangat ditentukan oleh asupan makanan yang dikonsumsi. Kualitas dan kuantitas makanan yang dikonsumsi anggota keluarga dipengaruhi oleh tersedia atau tidaknya makanan dalam keluarga yang nantinya akan memengaruhi asupan zat gizi. Karakteristik keluarga yang menjadi pertimbangan dan dapat memengaruhi pemenuhan nutrisi ialah pendapatan keluarga dan tingkat pendidikan ibu (Rahardjo, 2012).

Handayani, Mulasari, \& Nurdianis (2008) menjelaskan bahwa jika keluarga memiliki pendapatan yang besar serta cukup untuk memenuhi kebutuhan gizi anggota keluarga, pemenuhan kebutuhan gizi pada balita dapat terjamin. Pendapatan yang rendah menyebabkan daya beli rendah sehingga tidak mampu membeli pangan dalam jumlah yang diperlukan dan pada akhirnya berakibat buruk terhadap status gizi anak balita.

Hasil penelitian di Desa Kunden menunjukkan bahwa sebagian besar ibu yang memiliki anak usia 1-3 tahun memiliki pengetahuan tentang gizi anak usia toddler yang cukup baik dengan persentase sebesar $41,1 \%$. Sebanyak 19 responden $(33,9 \%)$ memiliki pengetahuan yang baik tentang gizi anak usia toddler dan sisanya memiliki pengetahuan yang kurang baik. Ibu merupakan orang yang berperan penting dalam penentuan konsumsi makanan dalam keluarga khususnya anak balita. Pengetahuan yang dimiliki ibu berpengaruh terhadap pola konsumsi makanan keluarga. Pengetahuan ibu yang kurang baik tentang gizi berakibat pada rendahnya anggaran untuk belanja, mutu pangan, keanekaragaman makanan, serta terganggunya status gizi balita (Lestari, 2006).

Seseorang yang memiliki pengetahuan gizi semakin baik akan semakin memperhitungkan jenis dan kuantum makanan yang dipilih untuk dikonsumsi (Putra, 2013). Notoatmodjo (2010) menyebutkan bahwa pengetahuan dipengaruhi oleh beberapa faktor, antara lain pendidikan dan motivasi. Observasi yang dilakukan oleh peneliti sesuai dengan teori yang disampaikan oleh Notoadmojo. Hasil observasi yang diperoleh peneliti saat melakukan kunjungan ke rumah ibu yang memiliki anak usia 1-3 tahun ialah ibu-ibu di Desa Kunden mayoritas memiliki pendidikan tinggi, yaitu lulusan SMA dan perguruan tinggi. Pendidikan yang tinggi akan membuat seseorang mudah dalam menyerap informasi yang diperoleh. Pendidikan yang tinggi juga memengaruhi seseorang untuk mengaplikasikan ilmu yang dimilikinya ke dalam kehidupan sehari-hari. Ibu-ibu di Desa Kunden menerapkan pengetahuan tentang gizi untuk memberikan makanan yang sesuai dengan kecukupan gizi anak sehingga anak memiliki status gizi yang optimal.

Hasil yang diperoleh dari penelitian di Desa Kunden ialah sebanyak 44 responden $(78,6 \%)$ telah menerapkan pola pemberian makanan yang baik. Tidak ada responden yang melakukan pola pemberian makanan yang kurang baik dan sisanya melakukan pola pemberian makanan yang cukup baik. Usia balita merupakan usia ketika seorang anak akan mengalami tumbuh kembang dan aktivitas yang sangat pesat dibandingkan dengan ketika masih bayi sehingga kebutuhan zat gizi akan meningkat dan pemberian makanan juga akan lebih sering. Anak usia batita mempunyai sifat konsumen pasif, yaitu anak belum dapat menyebutkan nama makanan yang diinginkan. Oleh sebab itu, orangtua bertugas mengatur dan 
memilihkan makanan yang bergizi untuk anaknya (Rusilanti \& Yulianti, 2015).

Pola pemberian makanan sangat penting diperhatikan oleh ibu. Ibu yang telah menanamkan kebiasaan makan dengan gizi yang baik pada usia dini tentunya sangat mudah mengarahkan makanan anak karena anak telah mengenal makanan yang baik pada usia sebelumnya (Sulistyoningsih, 2011). Pola pemberian makanan pada balita dipengaruhi oleh beberapa faktor, salah satunya pengetahuan gizi (Lestari, 2006). Observasi yang dilakukan oleh peneliti sesuai dengan teori yang disampaikan oleh Lestari. Hasil observasi yang diperoleh peneliti ialah sebagian besar ibu yang bekerja menitipkan anak pada neneknya. Pengalaman nenek dalam merawat dan mengasuh anak lebih banyak dibandingkan ibu sehingga pola pemberian makanan yang dilakukan baik. Salah satu cara memperoleh pengetahuan ialah dengan pengalaman sehingga peneliti memiliki pendapat yang sejalan dengan Lestari (2006).

Penelitian ini menggunakan indeks antropometri BB/TB yang baik untuk menilai status gizi saat ini. Penelitian ini menunjukkan responden yang memiliki status gizi tidak normal sebanyak 21 balita (37,5\%). Angka tersebut lebih besar jika dibandingkan dengan hasil survei yang dilakukan bidang gizi Puskesmas Karanganom pada Oktober 2015, yaitu $13,2 \%$ balita yang memiliki status gizi tidak normal. Masa balita merupakan periode penting dalam proses tumbuh kembang manusia. Perkembangan dan pertumbuhan di masa balita menjadi penentu keberhasilan pertumbuhan dan perkembangan anak di periode selanjutnya. Masa tumbuh kembang di usia ini merupakan masa yang berlangsung cepat dan tidak akan pernah terulang sehingga sering disebut golden age atau masa keemasan (Depkes, 2009).
Pertumbuhan dan perkembangan balita dipengaruhi oleh dua faktor determinan yang saling berinteraksi, yaitu faktor genetik dan faktor lingkungan. Faktor genetik mengacu pada faktor statik yang menyertai anak sejak pembuahan, sedangkan faktor lingkungan lebih berfokus pada kecukupan gizi dan kesehatan balita (Supariasa \& Fajar, 2012). Berat badan dan tinggi badan merupakan parameter antropometri yang memberikan gambaran massa tubuh. Balita dalam kondisi kesehatan yang baik dan seimbang antara konsumsi dan kebutuhan gizi akan memiliki berat badan yang linier dengan tinggi badan ketika perkembangan berat badan searah dengan pertumbuhan tinggi badan dengan kecepatan tertentu (Supariasa \& Fajar, 2012). Prevalensi balita yang mengalami status gizi tidak normal apabila tidak segera diatasi dapat menurunkan derajat kesehatan serta menghambat pertumbuhan dan perkembangan anak (Hidayat, 2009). Masalah gizi pada balita dapat diatasi dengan memberikan zat gizi yang adekuat sehingga dapat memperlancar pertumbuhan yang seimbang untuk pengangkutan oksigen dan nutrisi agar sel-sel dapat tumbuh untuk menjalankan fungsinya dengan normal (Hardiko, 2007).

Hasil penelitian di Desa Kunden ialah ibu dengan pengetahuan cukup baik yang memiliki balita dengan status gizi normal sebesar 48,6\%. Hasil uji koefisien kontingensi menunjukkan bahwa tidak ada pengaruh antara pengetahuan ibu tentang gizi balita terhadap status gizi balita. Pengetahuan gizi adalah segala sesuatu yang diketahui seseorang tentang sikap dan perilaku dalam memilih makanan, serta pengetahuan dalam mengolah dan menyiapkan makanan. Pengetahuan pangan dan gizi orangtua, terutama ibu berpengaruh terhadap jenis pangan yang dikonsumsi sebagai refleksi dari 
praktik dan perilaku yang berkaitan dengan gizi (Lestari, 2006).

Salah satu sebab terjadinya masalah gizi ialah kurangnya pengetahuan tentang gizi atau kurangnya kemampuan untuk menerapkan informasi tentang gizi dalam kehidupan sehari-hari. Pengetahuan ibu tentang gizi sangat diperlukan untuk dapat mengasuh anak dengan baik sehingga kebutuhan dan kecukupan gizi anak dapat terpenuhi dan anak memiliki status gizi yang baik. Ibu yang mempunyai pengetahuan tentang gizi balita yang baik cenderung memiliki anak dengan status gizi yang baik pula (Putra, 2013).

Hasil penelitian itu sejalan dengan penelitian Lestari, Lucia Endang, \& Budiyati (2013) juga menunjukkan hasil tidak ada hubungan antara pengetahuan ibu dan status gizi balita. Peneliti berasumsi bahwa penyebab perbedaan hasil penelitian ini dengan teori yang menyebutkan bahwa pengetahuan ibu berpengaruh terhadap status gizi balita, yaitu ibu yang menjadi responden kurang fokus dalam menjawab pertanyaan yang ada di dalam kuesioner. Kurang fokusnya ibu menjawab pertanyaan terjadi karena saat penelitian berlangsung anak sering rewel dan menangis.

Program penyuluhan terkait gizi balita yang dilakukan oleh petugas kesehatan di Puskesmas Karanganom belum dilakukan secara rutin sehingga ibu jarang memperoleh pengetahuan tambahan tentang gizi balita. Peneliti juga berasumsi bahwa ibu kurang memiliki motivasi untuk menambah kembali informasi mengenai gizi balita karena terlalu lelah bekerja sehingga pengetahuan ibu tentang gizi balita hanya cukup baik.

Peneliti juga berasumsi bahwa kuesioner yang digunakan dalam penelitian ini kurang dapat menggambarkan pengaplikasian pemahaman ibu tentang gizi balita secara menyeluruh karena jumlah pertanyaan yang sedikit dan belum mencakup keseluruhan materi tentang gizi balita sehingga perlu dilakukan perbaikan kuesioner. Lestari (2006) menawarkan kuesioner terkait pengetahuan ibu tentang gizi balita dengan item soal berbentuk multiple choice yang memiliki kelebihan, yaitu bersifat representatif dalam mencakup dan mewakili materi tentang gizi balita sehingga kuesioner tersebut dapat digunakan sebagai pertimbangan untuk penelitian selanjutnya.

Hasil penelitian yang dilakukan di Desa Kunden terkait pola pemberian makanan yang dilakukan ibu kepada anaknya ialah sebanyak 78,6\% ibu melakukan praktik pemberian makanan baik memiliki balita dengan status gizi normal. Hasil penelitian ini didukung dengan hasil uji statistik koefisien kontingensi yang menunjukkan bahwa pola pemberian makanan yang dilakukan ibu tidak berpengaruh terhadap status gizi balita.

Orangtua berperan penting dalam memberikan makanan yang bergizi pada anak balita, khususnya pada anak usia batita. Usia batita merupakan usia ketika anak bersifat konsumen pasif dan rentan terhadap penyakit gizi. Pola pemberian makanan yang dilakukan ibu berkaitan dengan cara dan situasi makan. Prinsip pemberian makanan juga harus disesuaikan dengan jenis makanan yang diberikan dan frekuensi makan dalam sehari. Kuantitas dan kualitas makanan yang dibutuhkan untuk konsumsi anak penting sekali dipikirkan, direncanakan, dan dilaksananakan oleh ibu. Pola pemberian makanan erat kaitannya dengan status gizi seorang anak.

Rusilanti \& Yulianti (2015) menyebutkan bahwa faktor yang cukup dominan menyebabkan masalah gizi kurang adalah praktik yang kurang benar di kalangan masyarakat dalam memilih dan memberikan makanan kepada anggota keluarga, terutama kepada anak-anak. Data Riskesdas-Depkes 
RI (2010) menunjukkan bahwa perilaku pemberian makanan yang benar kepada anak hanya 41,2\% (Badan Penelitian dan Pengembangan Kesehatan Kementerian Kesehatan RI, 2010).

Sulistyoningsih (2011) menyatakan bahwa ibu yang menanamkan kebiasaan makan yang baik balitanya akan memiliki status gizi yang baik pula.

Hasil penelitian tersebut sejalan dengan penelitian Hutagalung (2012). Hasil penelitian Hutagalung menyebutkan bahwa tidak ada hubungan yang bermakna antara pola pemberian makanan yang dilakukan ibu dan status gizi balita. Penelitian Istiono et al. (2009) juga menunjukkan hasil yang sama dengan penelitian ini bahwa perilaku ibu dan pengetahuan ibu tidak mempunyai korelasi signifikan dengan status gizi balita.

Sebagian besar ibu yang menjadi responden dalam penelitian ini merupakan ibu pekerja. Ibu yang bekerja sering menitipkan anaknya pada nenek. Peneliti berasumsi ibu tidak menjawab pertanyaan di kuesioner sesuai dengan pola pemberian makanan yang dilakukan oleh nenek sehingga data yang diperoleh tidak valid. Peneliti juga berasumsi bahwa ibu tidak menjawab pertanyaan sesuai dengan keseharian yang dilakukan. Jawaban responden yang tidak sesuai dengan keseharian disebabkan ibu tidak ingin memperlihatkan bahwa pola pemberian makanan yang dilakukan pada balita tidak tepat.

Peneliti juga berasumsi bahwa kuesioner yang digunakan dalam penelitian ini belum mencakup semua komponen yang terdapat dalam pola pemberian makanan sehingga hasil yang diperoleh kurang dapat menggambarkan kebiasaan ibu dalam memberikan makanan pada balita. Kuesioner yang baik digunakan dalam pola pemberian makanan sebaiknya disesuaikan dengan komponen-komponen yang terdapat dalam buku Kesehatan Ibu dan Anak (KIA) sehingga data lebih valid.

Peneliti juga berasumsi bahwa status gizi tidak normal yang terjadi pada anak balita di Desa Kunden bukan disebabkan oleh pola pemberian makanan. Faktor genetik atau faktor yang dibawa anak dari orangtua merupakan faktor yang menyebabkan anak memiliki status gizi tidak normal.

Pada penelitian ini tidak terdapat hubungan yang signifikan secara statistik antara pengetahuan ibu dan pola pemberian makan dengan status gizi pada balita. Hal ini dimungkinkan karena besar sampel yang relatif kecil dan jumlah item pertanyaan dalam kuesioner yang sedikit. Kelemahan penelitian ini ialah tidak mendatangi responden yang tidak hadir saat penelitian atau tidak sedang di rumah saat penelitian.

\section{SIMPULAN}

Hasil penelitian menunjukkan bahwa pengetahuan ibu tentang gizi anak usia toddler dan pola pemberian makanan tidak memiliki hubungan yang bermakna terhadap status gizi anak usia toddler di Desa Kunden. Saran bagi petugas kesehatan ialah meningkatkan kegiatan penyuluhan tentang gizi anak usia toddler pada ibu. Saran bagi peneliti selanjutnya ialah melakukan penelitian lebih lanjut dengan jumlah sampel lebih besar, jumlah pertanyaan lebih banyak.

\section{DAFTAR PUSTAKA}

Agustina, R. (2015). Hubungan dukungan keluarga dengan peningkatan berat badan balita gizi kurang di wilayah Puskesmas Jatinom (Skripsi). STIKES Muhammadiyah Klaten, Jawa Tengah, Indonesia.

Ayu, S. D. (2008). Pengaruh program pendampingan gizi terhadap pola asuh, kejadian infeksi dan status gizi balita kurang energi protein (Tesis). Program 
Pascasarjana Universitas Diponegoro, Semarang, Indonesia.

Badan Penelitian dan Pengembangan Kesehatan Kementerian Kesehatan RI. (2010). Hasil Riskesdas 2010. Jakarta: Bakti Husada.

(2013). Hasil Riskesdas

2013. Jakarta: Bakti Husada.

Bardosono, S. (2009). Masalah gizi di Indonesia. Majalah Kedokteran Indonesia, 59(1): 491-492.

Depkes RI. 2009. Sistem kesehatan nasional. Jakarta: Departemen Kesehatan RI.

Dinas Kesehatan Kabupaten Klaten. 2015. Profil kesehatan Klaten tahun 2015. Klaten: Bakti Husada.

Handayani, L, Mulasari, S.A., \& Nurdianis, N. (2008). Evaluasi program pemberian makanan tambahan anak balita. Jurnal Manajemen Pelayanan Kesehatan, 11(1): 21-26.

Hardiko. (2007). Mengenal pertumbuhan si buah hati. Klaten: Cempaka Putih

Hidayat, A.A.A. (2009). Pengantar IImu Keperawatan Anak I. Surabaya: Salemba Medika.

Hutagalung, H. (2012). Faktor-faktor yang mempengaruhi status gizi balita (12-59 bulan) di Desa Bojonggede Kabupaten Bogor tahun 2012 (Skripsi). Fakultas Kesehatan Masyarakat, Universitas Indonesia, Jakarta, Indonesia.

Istiono, W., Suryadi, H., Haris, M., Irnizarifka, Tahi, A. D., Hasdianda, M. A., Fitria, T., Sidabutar, T. I. R. (2009). Analisis faktorfaktor yang mempengaruhi status gizi balita. Berita Kedokteran Masyarakat, 25(3): 150-155.

Kusharto, C.M. dan Supariasa, I. D. N. (2014). Survei konsumsi gizi. Yogyakarta: Graha IImu.

Lestari, E. (2006). Faktor-faktor yang mempengaruhi pola pemberian makanan balita pada keluarga petani di
Dusun Mandungan Srimartani Piyungan Bantul, Yogyakarta (Skripsi). Fakultas Teknik, Universitas Negeri Yogyakarta, Yogyakarta, Indonesia.

Lestari, T. W., Lucia Endang Y. K., \& Budiyati. (2013). Pengaruh pemberian makan balita dan pengetahuan ibu terhadap status gizi balita di Kelurahan Meteseh Kecamatan Tembalang Kota Semarang. Semarang. Prosiding Seminar Nasional Keperawatan Meningkatkan Kesejahteraan Ibu dan Anak Sejak Dini dalam Rangka Mewujudkan Keberlanjutan (Sustainability Program MDGs 2015), 310-319. Semarang, Indonesia: Universitas Muhammadiyah Semarang.

Maryunani, A. (2010). IImu kesehatan anak dalam kebidanan. Jakarta: Trans Info Media.

Miller, J. E. \& Rodgers, Y. V. (2009). Mother's education and children's nutritional status: new evidence from Cambodia". Asian Development Review, 26(1): 131165.

Morks, F. J., Knoers, A. M. P., \& Haditono, S. R. (2001). Psikologi perkembangan: Pengantar dalam berbagai bagiannya. Yogyakarta: Gajah Mada University Press.

Mubarak, W. I. (2011). Promosi kesehatan untuk kebidanan. Jakarta: Salemba Medika.

Notoatmodjo, S. (2007). Kesehatan masyarakat: IImu dan seni. Jakarta: Rineka Cipta.

Notoatmodjo, S. (2010). Promosi kesehatan dan ilmu perilaku. Jakarta: Rineka Cipta.

Prasetya, Y. (2012). Analisis faktor yang mempengaruhi status gizi balita di Posyandu Kenanga II Desa Ngreden Kecamatan Wonosari Klaten (Skripsi). STIKES Muhammadiyah Klaten, Jawa Tengah, Indonesia. 
Proverawati, A. \& Kusumawati, E. (2011). IImu gizi untuk keperawatan dan gizi kesehatan. Yogyakarta: Nuha Medika.

Putra, S. R. (2013). Gizi dan diet. Yogyakarta: D-Medika.

Rahardjo, K. (2012). Asuhan neonatus, bayi, balita dan anak prasekolah. Yogyakarta: Pustaka Pelajar.

Rusilanti, M. D. \& Yulianti, Y. (2015). Gizi dan kesehatan anak prasekolah. Bandung: PT Rosdakarya.

Santoso, S. (2008). Kesehatan dan gizi. Jakarta: Rineka Cipta.

Santrock, J. W. (2002). Life-Span Development (Jilid 2). (Alih bahasa: Achmad Chusairi). Jakarta: Erlangga. (Naskah asli terbit 1999).

Sulistyoningsih, H. (2011). Gizi untuk kesehatan ibu dan anak. Yogyakarta: Graha IImu.

Supariasa, I. D. N. \& Fajar, I. (2012). Penilaian status gizi. Jakarta: EGC.

UNICEF Indonesia. (2012). Gizi ibu \& anak. Jakarta: Ringkasan Kajian.

World Health Organization. (2016). Infant and young child feeding. Retrieved from http://www.who.int/news-room/factsheets/detail/infant-and-young-childfeeding. 